\title{
The Multiculturalism and the spiritual identity of Europe
}

\author{
PhD. Traian-Alexandru MIU \\ Faculty of Theology and Educational Sciences, \\ Valahia University of Târgoviște, \\ ROMANIA, \\ E-mail: traianalexandrumiu@gmail.com
}

\begin{abstract}
Europe must manage the large number of cultures that practically "collide". This is the result of increasing migration and excessive emphasis on economic development at the expense of revaluation of spiritual roots of this civilizational space. In this context, the multiculturalism has become a leitmotif of Western policy. In fact, the multiculturalism can be defined as a normative political theory, which wants to regulate the new situation created by cultural minorities. Unlike the cultural pluralism, which aims acceptance of different cultures and the living together in a given society, the multiculturalism promotes the multiplication of diversity, the idea of blurring nationalist trends, the ridding of minorities traditions and our immersion in the hipermodernism. In the reality imposed by multiculturalism matter only the progress that is inconsistent with the idea of cultural heritage. Today, more and more voices in the political world began to criticize the political and social model imposed by multiculturalism and reaffirm the return to spiritual and cultural values that define Europe.
\end{abstract}

Keywords: multiculturalism; cultural pluralism; spiritual identity; hipermodernism; cultural minorities;

\section{Introduction}

What is happening today in Europe? What will be the future of this continent and how it will solve the problems associated, on the one hand, with the multitude of cultures and, on the other hand, which are valences of the meeting between them? In fact, we must ask what is Europe - a geopolitical space or a model of civilization? What were its identitary basis, how did it work? He did it and makes it work only economic engines? These are questions that require more attention from us, are challenges addressed both those who believe in a united Europe that is based on a spiritual identity, but also to those who consider the European project as being "kept alive" only by the economic factors. Becomes acute the alarm signals that warns that Europe goes through a critical period. Is the desperate cry of various forms of crisis: economic, demographic, and migrational and, primarily, of the spiritual identity. In this article I will briefly analyze the challenges of multiculturalism in Europe and those of the spiritual identity of this part of the world.

\section{Multiculturalism versus Cultural Pluralism}

Should be made clear from the outset that the multiculturalism is a political theory with normative character, differing from the cultural pluralism which involves the coexistence in a society of at least two cultural communities (ethnic, national, religious), each aimed preserving their characteristic identity, values and traditions of its members.[1]

As political theory with normative sense, multiculturalism reacts to "one of the phenomena resulting from the presence of multiculturality in most of the current states: the explosion of applications to accommodate the difference from the cultural minorities. These claims have not come or do not come only from ethnic minorities, national or religious. 
Many of them came or come from the sexual minorities, feminist organizations, people with unconventional lifestyles or persons with disabilities" [2].

The cultural pluralism is a concept that aims acceptance and living together of different cultures in a given society.

The first to use the term "cultural pluralism" is Horace M. Kallen, in 1915, he imagined a nation made up of multi-ethnic European nations, built after the model of "American civilization", who use English as the common language. In Kallen's view, the outline of a great and truly democratic commonwealth can become perceptible. The form that would have it would be that of a federal republic, that would have as "engine" the democracy of the nationalities meant to cooperate voluntarily and autonomously through shared institutions.[3]

The cultural pluralism is the very basis of a society in which individuals can form and develop communities despite the differences in race, age, sex, religion, language and lifestyles. These communities are open systems, and the members can choose to belong to one or several communities simultaneously.

This condition can only exist in a society where there are two or more cultural functional communities, and these communities to adhere to a code of valid values for each one and to promote the use of society's resources for satisfying the needs of all its members. This is considered to be achieved in a society where different cultural communities are recognized and are allowed to participate in, and control those functions and resources considered vital for the proper functioning of the community. Cultural pluralism can not exist in a society in which different cultural communities are living in isolation from each other and / or in competition, in unequal conditions for the sustainability of life or to increase the resources that society produces.[4]

Among the main objectives of the cultural pluralism we can mention the following: helping the ethnic groups in order to strengthen and preserve their identity; overcoming the barriers they face when they want to participate in social and cultural life of the society which received; increased cultural exchanges; supporting immigrants for the easily adaptation to new cultural processes; intercultural fusion.

The multiculturalism was born as a reaction to the cultural pluralism, being a political theory with normative character that wants to regulate the new situation created by cultural minorities. So, in itself, between pluralism and multiculturalism is not a gap, there is no incompatibility. In the event that the multiculturalism is perceived as a form of highlighting the existence of several cultures in a society, it does not conflict with the pluralistic conceptions about the world. Between cultural pluralism and multiculturalism the incompatibilities arise when the latter is considered as a "priority value". In this case the risks of a conflict are evident.

The pluralism involves the assumption of diversity, but do not promote the multiplication of diversity, does not consider that a better world necessarily mean a world very diversified. Pluralism presupposes tolerance and the tolerance means acceptance not promoting of otherness. The aim of pluralism is the integration, and for it to be done it is recommended that the percentage of assimilation to be in relation to the need for integration, not to be overcome, not to arriving at homogeneity, which is not desirable.[5]

Unfortunately, "today's dominant version of multiculturalism is one anti pluralistic. In fact, its intellectual origins are Marxist. Before stopover in the United States and to Americanize, the multiculturalism extracts its vigor from the neo-Marxists Brits, in their turn powerful leaven by Foucault; and spreads on Universities (Colleges) with the 
introduction of the "cultural studies" which focuses on hegemony and "domination" of a culture on others." [6]

\section{The multiculturalism in the European area}

The multiculturalism has now become a kind of leitmotif of Western policy, bearer of primordial, universal and undeniable values. Multiculturalism has managed to impose himself by changing the meaning of modernity which no longer corresponds the balance between what we inherited and progress, between memory and utopia. In the reality imposed by multiculturalism counts only the progress, that is inconsistent with the idea of cultural heritage, and creating a world where borders to be abolished.

Because it the ideals of multiculturalism to have finality, is promoted the idea of diminishing nationalistic tendencies, also the elimination of minority traditions and our immersion in hypermodernism. This leads progressively to the disqualification of popular sovereignty in favor of potentiation of the political factor, leading to a substitution of human rights with democratic sovereignty.

The European Union promoted the multiculturalism through the political elites to the masses of people, creating institutions that preserve and cultivate diversity and, at the same time, to monitor and protect the "rights and identity of the cultural or the religious minorities. The slogan 'unity in diversity' of the European Union is edifying for the philosophy approached by this supranational organism, through the emergence of a common identity, consciously accepted, synchronous and politically motivated by all the constituent parts for accepting European identity. Different moments of formation of the component parts - minority community is formed in existing society a priori - and maintaining of group identity are reflected asymmetry of the multiculturalism."[7]

European Union perspective on the multiculturalism, influenced by the theories of sociologists Émile Durkheim and Ferdinand Tönnies, envisages the developments on the social level, from the stage where communities arise because of certain common features (language, code of ethics, cultural similarities, external physical resemblance etc.), reaching gradually to the birth of a community that is based on the interdependence of individuals within the same group.[8]

In Europe, the multiculturalism is primarily address to the first or second generation of immigrants or refugees.[9] And, in this situation, over time, the multiculturalism has suffered numerous critics. Thus, in October 2010, the German Chancellor, Angela Merkel, referring to the vast Muslim communities in his country, said about multiculturalism that is "a total failure" and the idea that members of different cultures can live happily "side by side" did not work.[10] In the context of immigrants crisis, in December 2015, at a meeting of her Christian Democratic Union party, Angela Merkel said that "those who seek refuge with us also have to respect our laws and traditions, and learn to speak German"[11]. Also, referring to the multiculturalism, she said that "he leads to parallel societies, and therefore multiculturalism remains a grand delusion."[12].

After the declaration of Angela Merkel in October 2010, another great European leader, David Cameron, affirming the need for a national identity as strong in order to confront and dismantle extremist ideologies, in February 2011, declared: "Under the doctrine of state multiculturalism, we have encouraged different cultures to live separate lives, apart from each other and the mainstream. We have failed to provide a vision of society to which they feel they want to belong. We have even tolerated these segregated communities behaving in ways that run counter to our values. So when a white person holds objectionable views - racism, for example - we rightly condemn them. But when equally 
unacceptable views or practices have come from someone who isn't white, we've been too cautious, frankly even fearful, to stand up to them." [13]

Joining the growing number of critics of the multiculturalism, in February 2011, the European political leader Nicolas Sarkozy invited to a show of the TV station TF1, declared that the multiculturalism is a "failure" in Europe. In connection with this subject, said the following: "The truth is that in all our democracies, we're too concerned with the identity of the people coming in and not enough with the identity of the country that's taking them in. We don't want a society in which communities co-exist alongside each other. If you come to France, you agree to base yourself in a single community, the national community. If you don't accept that, you don't come to France.'[14] Next, Sarkozy spoke of the impact that has Islam on French society, but in the context of in which Islamic community in France is the largest in Europe, he believes that his compatriots Muslims "should be able to live and practice their religion like anyone else ... but it can only be a French Islam and not just an Islam in France. ... Our Muslim compatriots must be able to practise their religion, as any citizen can, but we in France do not want people to pray in an ostentatious way in the street. ... The French national community cannot accept a change in its lifestyle, equality between men and women and freedom for little girls to go to school'"[15].

The statements of these three important European political leaders are significant in this context in which immigration boomed in Europe. Multicultural policies, that have been promoted within the European Union, seems to do not have the desired effect, therefore, now is trying an affirmation of the fundamental values of each state, an applied integration of immigrants into the national communities.

\section{Spiritual identity of Europe}

The European Community puts today, more often, the issue of the Christian roots to build the Europe of tomorrow. During the drawing up the European Constitution in 2005, the debate on recognition of the role of Christianity in forming Europe was very tense, the end result being the rejection of the mention of the Christian roots in the Constitution.

The issue of the Christian roots of Europe was again restarted on 9 May 2016, when the European Commissioner for Economic and Monetary Affairs, Pierre Moscovici, former Minister of Economy and European Affairs in France, was asked what he thinks about election as mayor of London of an Muslim, Sadiq Khan, a first in the history of Western Europe for a capital, he responded: "Europe, even if it's true that on our continent a majority of the population are, let's say of Christian religion or culture, Europe is not Christian. I don't believe in the Christian roots of Europe. I believe Europe is diverse, united and diverse" $[\mathbf{1 6}]$.

From a historical perspective, denying the Christian roots of Europe is a serious error. Europe was born on the ruins of the Roman Empire, Christianity became the official religion thanks to the proclamation of the Edict of Milan in 313, by Emperor Constantine the Great. It is also the result of the long and the ordeal confrontation between the Germanic peoples converted to Christianity to dominate the continent politically. The baptism of Clovis in 498, then the Carolingian alliance with the pope, was decisive stages that have led to the formation of Europe. Charlemagne's empire, proclaimed in 800, which included in large part the territory that corresponds to Western Europe, was Christian. Charlemagne sets the target to convert its neighboring peoples and the beginning of Muslim Spain reconquest. For almost thirteen centuries, until the eighteenth century, Christianity was the one who was the link between the European societies. It must be said that during the Middle-Ages obscure periods, when Europe suffered from the chaos of invasion, monasteries and abbeys 
were keepers of the cultural heritage of Christian Europe. The Christianity, along with his rituals, leaves its mark on everyday life of citizens. Through the Church are created the first educational institutions, first hospitals, the first charitable operas are performed. Everyday life of European citizens is governed by the spirit of Christian living. So whether it is about epidemics or healings, rich or poor harvests of the field, victory or defeat in military campaigns, all are subordinated to divine Providence. Architectural Heritage of Europe itself clearly bears the imprint of the Christian influences, churches are those that have a decisive role in this regard, by their presence everywhere.[17]

If in the Middle Ages Europe could be characterized as a universitas Christiana, from about 50 years was promoted the model of a multicultural Europe, which denies its Christian contribution to the formation of Europe. Denying the Christian roots of Europe is the consequence of secularization and of the whole corollary of postmodern and hypermodernist influences, between them the secularization occupies a prominent place.

Referring to the future of Europe, at the social-political course and its culturalspiritual identity, the great French medievalist historian Jacques Le Goff, said the following: "Europe is under construction. Behold a great hope that will come about only if it takes into account the history: a Europe without history would be orphan and miserable. Because today comes from yesterday's, and tomorrow is the fruit of the past. A past that must not paralyze the present, but to help them to be different in fidelity and progress in new. Between Atlantic, Asia and Africa, our Europe really exist by very long time, drawn by geography and shaped by history, since the time when the Greeks gave her the name it bears. The future must be based on these legacies which, since antiquity, even in prehistoric times, have enriched Europe gradually, making it extraordinarily creative in unity and diversity, inclusively in a wider global context. '[18]

Unquestionably, Europe still is not lacking in a Christian soul and can still assert its spiritual dimension, but for this to happen it requires effort and sustained involvement of European Christianity as a whole, therefore of all Christian confessions. Europe vitality is the consequence of Christian spirituality, from whose heart pulsates and propels values.

\section{Conclusion}

The multiculturalism as a policy strategy is becoming increasingly contested by the high European officials and by people who make up actually the true European unity that has developed feeding through its Christian roots.

Certainly the numbers of those who, like Pierre Moscovici, want a uprooted Europe, are many. They believe in a Europe in which only the contribution to the economic welfare matters. In fact, it is possible that their project to be based exactly on Europeans uprooted, in order to create a "Union", in future, where to be received countries such as Turkey, countries that forming the Maghreb, or even the entire African continent. Is it desirable and will be functional a Europe in which nationalities does not matter anymore, particular cultures to be replaced by a "culture of money", to prevail the immigrants, as cheap labor exponents? Certainly the parents of the European project, Monnet, Schuman, Adenauer, De Gasperi, Spaak, Mitterrand, Kohl, Andreotti, Delors did not believe in a European Union where the market prevail. A Europe without Christian roots will be nothing else but a soulless Europe, handcuffed by the non-values dictated by financial markets, by the banks a society of selfishness and of mediocrity that will not in any way take account of the true values. 


\section{REFERENCES}

[1] Eugen Huzum, „Ce este multiculturalismul?”, in Ana Gugiuman (coord), Idei şi valori perene în științele socio-umane. Studii şi cercetări, Ed. Argonaut, Cluj-Napoca, 2009, p. 45 ;

[2] Ibid;

[3] Dr. Antonia Pantoja, Dr. Wilhelmina Perry, Dr. Barbara Blourock, „Towards the Development of Theory: Cultural Pluralism Redefined", in The Journal of Sociology \& Social Welfare, vol. 4, oct. 2014, pp. 127-128;

[4] Ibid, p. 130-131;

[5] Giovanni Sartori, Ce facem cu străinii? Pluralism vs. multiculturalism. Eseu despre societatea multietnică, trad. rom. Geo Vasile, Ed. Humanitas, București, 2007, pp. 51-52;

[6] Ibid, p. 53;

[7] ***, „Multiculturalismul în Europa. În agonie”, in rev. Sinteza,web: http://revistasinteza.ro/multiculturalismul-in-europa-in-agonie/;

[8] Ibid;

[9] Gerard Delanty, Community, Ed. Routledge, USA and Canada, 2010, p. 80;

[10] Matthew Weaver, „Angela Merkel: German multiculturalism has 'utterly failed'،, The Guardian, Sunday 17 October 2010. See web adress: https://www.theguardian.com/world/2010/oct/17/angela-merkel-german-multiculturalismfailed

[11]Ryan Grenoble, „Angela Merkel Calls Multiculturalism 'A Grand Delusion”,, The Huffington Post, 14.12.2015, web: http://www.huffingtonpost.com/entry/angela-merkelgermany-multiculturalism_us_566f2e15e4b0fccee16f7757;

[12] Ibid;

[13] Patrick Wintour, „David Cameron tells Muslim Britain: stop tolerating extremists”, The Guardian, 5.02.2011, web: https://www.theguardian.com/politics/2011/feb/05/davidcameron-muslim-extremism;

[14]***, „Le multiculturalisme est “un échec”, affirme Nicolas Sarkozy”, Le Point, 10.02.2011, web: http://www.lepoint.fr/societe/le-multiculturalisme-est-un-echec-affirme-nicolassarkozy-10-02-2011-1294163_23.php\#;

[15] Ibid;

[16]***, „Pierre Moscovici "ne croit pas aux racines chrétiennes de l'Europe”“, Valeures Actuelles, 09.05.2016, web: http://www.valeursactuelles.com/societe/pierre-moscovici-necroit-pas-aux-racines-chretiennes-de-leurope-61643;

[17] Maxime Tandonnet, „Racines chrétiennes de l'Europe: réponse à Pierre Moscovici”, Le Figaro, 09.05.2016, web: http://www.lefigaro.fr/vox/politique/2016/05/09/31001 20160509ARTFIG00084-racines-chretiennes-de-l-europe-reponse-a-pierre-moscovici.php;

[18] Jacques Le Goff, Evul Mediu şi naşterea Europei, trad. rom. Giuliano Sfichi and Marius Roman, Ed. Polirom, București, 2005, p. 9; 